\title{
Formas do signo interpretante na expressão visual e sonora da ambiência de um vídeojóquei
}

\author{
Autor: Guilherme Henrique de Oliveira Cestari \\ Orientador: Miguel Luiz Contani
}

Resumo: Este trabalho examina a operação de signos visuais e sonoros em uma ambiência urbana de entretenimento, em particular a configuração do interpretante desses signos no resultado luminoso e catártico produzido em apresentações videográficas. A noção semiótica de raciocínio diagramático é utilizada para descrever e analisar as aparições do personagem de um palhaço em um show de música eletrônica da dupla britânica The Chemical Brothers, corpus selecionado para estudo. São analisados os usos e percursos da imagem e das sonoridades no momento em que se desenrola a ação, com máscara e transe sendo mobilizados para exercer influência de cunho hedonista, fantasmagórico, carnavalesco e ritualístico sobre o público presente. A atuação clownesca inclina-se a produzir interpretantes, inicialmente de caráter emocional e, posteriomente, de natureza energética, estabelecendo, de forma incisiva, vínculos identitários com a plateia. Analisamse os desdobramentos das aparições do referido personagem (que é inserido de diferentes maneiras na performance para conduzir mensagens persuasivas), e os efeitos advindos da conjunção entre som e imagem que se propaga de modo sincrônico, ambivalente e profuso, em meio a uma aglomeração de pessoas, uma paisagem urbana e um fenômeno lúdico. Foi elaborado um guia de análise no formato de uma espiral, para com ela inferir acerca do funcionamento dos signos interpretantes na ocorrência do VJing, modalidade de semiose própria da atuação do videojóquei nesse tipo de evento, em que se impregnam efeitos identitários e mnésicos nas culturas e hábitos metropolitanos, no caráter libertário e efervescente da festa, na fruição emocional da audiência.

Palavras-chave: Sinais e símbolos na comunicação visual, Vídeo jockey, Vjing, Som e imagem, Alegorias, Música eletrônica 


\title{
Forms the interpretant sign in visual and sound expression of ambience of a videojóquei
}

\begin{abstract}
The focus of this work is the operation of visual and audio signs in an urban ambience of entertainment, particularly the arragement of the interpretant of these signs in the luminous and cathartic output of video presentations. The semiotic concept of diagrammatic reasoning is used to describe and analyze the apparitions of a clown character in an electronic music show of the British duo The Chemical Brothers, selected corpus for the study. The analyses cover the uses and the track of images and sounds at the moment the action takes place, with mask and trance being mobilized to exert hedonist, phantasmagoric, carnivalesque and ritualistic influence on the audience. The acting clown tends to produce interpretants, initially of an emotional and, subsequently, of an energetic nature, so as to incisively establish identity links with the audience. The developments of the character's apparitions (which is inserted into the performance in different ways to yield persuasive messages) are analyzed along with the effects resulting from the conjunction between sound and image which propagates in a synchronic, ambivalent and profuse manner, amid a crowd, an urban landscape and a playful phenomenon. A spiral shape guide was prepared to support the analysis and enable to infer about the work of the interpretant signs from the VJing, a kind of semeiosis typical of the videojockey's action in this sort of event. Identity is then impregnated and so are mnemonic effects on the metropolitan cultures and habits, in the libertarian and effervescent nature of the party, on the emotion fruition reached by the audience.
\end{abstract}

Keywords: Sound and imaging, Allegories, Electronic music.

Dissertação completa disponível em: http://www.bibliotecadigital.uel.br/ document/?code $=$ vtls000190574 